\title{
Impact of HIV Infection and HAART Therapy on CD4 T Helper Cell Subset Expression and Function
}

\author{
Christina Guzzo*, Nor Fazila Che Mat*, Xiubo Zhang* and Katrina Gee \\ Department of Biomedical and Molecular Sciences, Queen's University, Kingston, ON
}

Canada

\section{Introduction}

\subsection{Th cell development}

Regulation of $\mathrm{T}$ helper (Th) cell differentiation and proliferation depends on which cytokines are present in the microenvironment of a naïve Th cell. Induction of specific transcription factors results in programming of the naïve Th0 cell into one of several subsets. Currently there are four well characterized Th cell subsets, namely Th1, Th2, Th17, and the T regulatory (Treg) cells (Figure 1). In this chapter we will be focusing on the Th1, Th17, and Treg cell populations. However, at this point it is also worth mentioning the relatively newly described Th9 and follicular (Tfh) cell subsets. Here we briefly discuss the differentiation pathways taken by a Th0 cell that ultimately results in the formation of these different subsets.

Since the early 1980's, the Th1/Th2 paradigm has been well-studied. Th1 cells are known for expression of the signature cytokine IFN- $\gamma$ and resulting anti-viral activities. The necessary driving cytokine for these cells is IL-12 in conjunction with the Th1-specific transcription factor T-bet (Hsieh, Macatonia et al., 1993; Seder, Gazzinelli et al., 1993;Szabo, Sullivan et al., 2002). IL-27, related to IL-12, has been recently shown to play a role in the induction of Th1 cells, while also actively repressing development of other subsets. On the other hand, Th2 cells are largely recognized to support humoral immunity and are induced by the presence of IL-4 and resulting activation of the STAT6 transcription factor(Kaplan, Schindler et al., 1996;Kurata, Lee et al., 1999). Equally important is the activation of the GATA binding protein 3 (GATA-3), the main regular of Th2 development (Pai, Truitt et al., 2004;Zhu, Min et al., 2004). The newly defined Th17 cells have been implicated in a number of inflammatory disorders and are recognized as key Th cells that trigger massive proinflammatory responses. They are characterized by production of IL-17 and differentiation of these cells requires both tumor growth factor (TGF)- $\beta$ and IL-6 which act together to promote development of the Th17 subset (Bettelli, Carrier et al., 2006; Mangan, Harrington et al., 2006). Additionally important to the generation of these cells is IL-23, which functions to aid in the development and proliferation of Th17 cells. The key transcription factors required belong to the retinoic acid-related orphan receptors (ROR)

\footnotetext{
* Authors contributed equally to this work.
} 
family; both ROR-a and RORyt have been shown to be critical to Th17 development (Yang, Pappu et al., 2008). The Treg cell subset is crucial to the regulation of immune responses as these cells play a suppressive role, mainly via the expression of the anti-inflammatory cytokine IL-10. These cell subsets are unique from the other subsets as they can be formed either in the thymus (known as "naturally" occurring Tregs or nTreg) or as a result of TGF- $\beta$ stimulation and $\mathrm{T}$ cell receptor (TCR) triggering (known as "inducible" Tregs or iTreg)(Murai, Krause et al., 2010). The main transcription factor for the development of these cells is Foxp3 which is only expressed in Treg cells (Zheng \& Rudensky, 2007). Th9 cells have been recently identified as IL-21-dependent CD4 T cells producing IL-9, although a key function has yet to be identified for these cells, it appears that they may be involved in inflammation and allergy (Xing, Wu et al., 2011; Ma, Tangye et al., 2010; Wong, Ye et al., 2010). The Tfh cells are newly defined to be efficient producers of IL-10 and IL-21 (Suto, Kashiwakuma et al., 2008; Crotty, 2011). These cells generally express high levels of CXCR5 and are responsible for providing support for B cells (Crotty, 2011). Key to the differentiation of these cells, are IL-6 and IL-21 which mediate the induction of the transcription factor Bcl-6 (Nurieva, Chung et al., 2009).

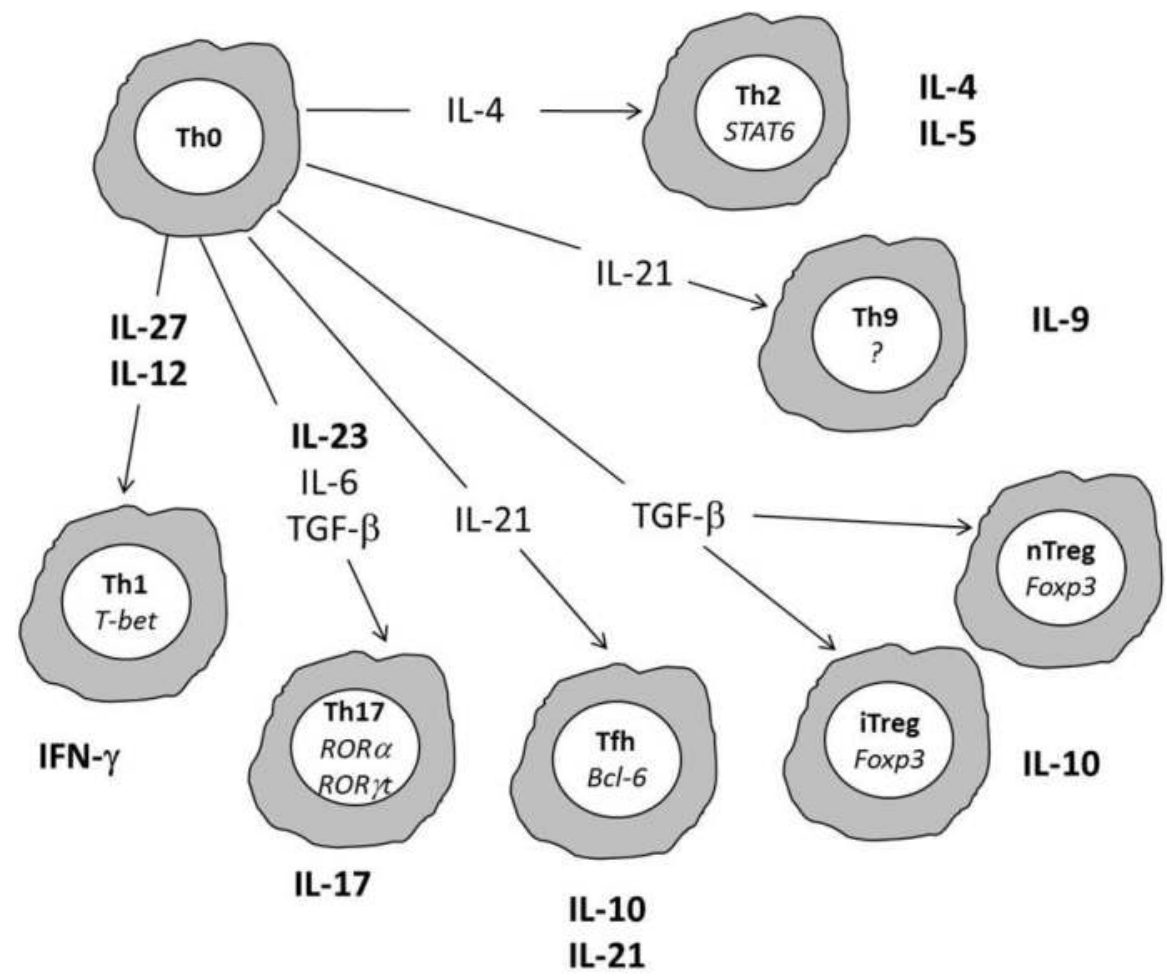

Fig. 1. CD4 T cell Differentiation Pathways: Naïve T cells (Th0) cells can differentiate into different subsets of T cells depending on the cytokine(s) present in the cell environment. Shown in this diagram are the cytokines required for each cell type, the transcription factors required for each cell type (in italics), and the main cytokine(s) produced by each cell type (in bold). 
The IL-12 family of cytokines is composed of IL-12, IL-23, and IL-27, with each of these cytokines playing a different role in Th cell development. Proper regulation of the development and differentiation of CD4 T cells is critical to an effective immune response. As these cells are the main target of HIV infection, the resulting loss and imbalance of the Th cell subsets are a hallmark of HIV and AIDS. The remainder of this chapter will be devoted to a discussion of the impact of HIV infection on the function and expression of the IL-12 cytokine family members as it relates to Th cell differentiation and function with a focus on how Th1, Th17, and Treg CD4 T cell subsets are affected.

\section{IL-12 and HIV infection}

IL-12 is critically involved in generating cell-mediated immune responses to infectious agents, including HIV. Biologically active IL-12p70, a dimer of IL-12p35 and IL-12p40, is secreted by activated monocytes, macrophages, and dendritic cells. IL-12 expression drives the production and development of the Th1 subset of $\mathrm{T}$ cells, and is responsible for the induction of IFN- $\gamma$ expression from these cells(Alber, Al-Robaiy et al., 2006).

IL-12 production is impaired in HIV-infected individuals and in cells infected in vitro with HIV (Chehimi, Starr et al., 1999; Daftarian, Diaz-Mitoma et al., 1995; Boucher, Parato et al., 2010;Buisson, Benlahrech et al., 2009). In terms of IL-12 receptor chain expression (IL-12R $\beta 1$ and IL-12R $\beta 2$ ), one study reported that resting peripheral blood mononuclear cells (PBMC) from HIV positive patients and HIV negative controls did not express IL-12R $\beta 1$ or IL-12R $\beta 2$ chains on their cell surface (Jones, Young et al., 2003). Upon examination of mRNA levels, the group found that levels of both receptor subunits were markedly reduced in HIV positive patients compared to HIV negative controls. Culture of activated cells with IL-12 resulted in upregulation of the IL-12R $\beta 2$ chain suggesting that treatment with IL-12 may serve to recapitulate IL-12R levels and thus IL-12 responses (Jones, Young et al., 2003). In contrast, a recent study demonstrated that unstimulated CD4 T cells from HIV-1 positive patients expressed a two-fold increase of IL-12R $\beta 1$ subunit compared with cells from HIV-1 negative controls (de Arquer, Pena et al., 2007). Similar to Jones et al (2003), this group found that stimulation of the CD4 T cells with IL-12 resulted in the enhancement of IL12R $\beta 2$. Together these two findings illustrate the potential importance of restoring IL-12 mediated responses, particularly in view of the role of IL-12 in Th1 cell differentiation and IFN- $\gamma$ production.

The above observations suggest that although the virus inhibits IL-12 production, the immune cells attempt to bolster responses via upregulation of IL-12 receptor levels, which leads to speculation that treatment with IL-12 may be beneficial to patients. In in vitro models using T cells isolated from HIV patients, enhanced immune responses are observed upon treatment of these cells with recombinant IL-12 (Landay, Clerici et al., 1996). Vectors expressing IL-12 have also been used successfully in candidate vaccines in animal models (Chong, Egan et al., 2007; Boyer, Robinson,et al., 2005; Egan, Chong et al., 2005;Hirao, Wu et al., 2008). IL-12 is important for the priming of antigen-specific T cells, as demonstrated by a study using IL-12 deficient mice. Mice were immunized with HIV gp120 cDNA vectors and the cytotoxic $\mathrm{T}$ cell response in IL-12 deficient mice was significantly lower compared to wild type mice. Furthermore, reconstitution of IL-12 in the deficient mice was able to restore T cell responsiveness (Gupta et al., 2008). However, toxicity of IL-12 as a treatment option is a concern. Therefore, use of other cytokines which may have less toxicity, such as IL-23 or IL-27 is of interest. Additionally, treatment with anti-receptor or anti-cytokine antibodies to 
IL-12 and IL-23 has proven useful in treatment of autoimmune diseases(Ding, $\mathrm{Xu}$ et al., 2008;Elson, Cong et al., 2007;Gottlieb, Cooper et al., 2007;Krueger, Langley et al., 2007). Treatment with recombinant IL-27 has also proven useful in an in vitro model of arthritis (Niedbala, Cai et al., 2008). Together, these points indicate alternative recombinant cytokine treatments could be applied in emerging HIV therapeutics.

\section{IL-27 and HIV infection}

IL-27 was first discovered in 2002 by Pflanz et al. as a novel member of the IL-12 family of cytokines (Pflanz, Timans et al., 2002). This family is comprised of molecules sharing subunits and receptor chain components; therefore, IL-27 and IL-12 have similar functions. IL-27 engages a heterodimeric receptor composed of gp130 and WSX-1 (Pflanz, Hibbert et al., 2004). Numerous immune cells respond to IL-27, as the IL-27 receptor can be found on endothelial cells, mast cells, activated B cells, monocytes, Langerhans cells, activated DCs, and polarized Th cells (Larousserie, Charlot et al., 2006; Lucas, Ghilardi et al., 2003; Pflanz, Hibbert et al., 2004;Ruckerl, Hessmann et al., 2006;Wirtz, Tubbe et al., 2006). Functionally, IL-27 exhibits proand anti-inflammatory properties and, thus, IL-27 can be regarded as an immunomodulatory cytokine. Recent evidence has indicated a role for IL-27 in the regulation of monocyte/macrophage function (Guzzo, Che Mat et al., 2010; Kalliolias \& Ivashkiv, 2008), in addition to its well-characterized functions in T cells. IL-27, predominantly produced by activated monocytes and dendritic cells, can bridge innate and adaptive immunity by playing a key role in the activation of naïve T cells and differentiation to Th1 cells.

A role for IL-27 in the control of HIV replication was first described in 2007 (Fakruddin, Lempicki et al., 2007). This study evaluated the effects of HPV-VLPs (Human Papilloma Virus - Virus-Like Particles) on HIV-1 replication in PBMC, CD4 + T cells, and macrophages. Using the p24 antigen capture assay to assess viral replication, this study showed treatment with HPV-VLPs could suppress replication of both X4 and R5 strains of HIV-1. This suppression was independent of any effect on cell surface expression of CD4, CXCR4, or CCR5, as analyzed by surface staining and flow cytometry. Upon observing the anti-HIV effect of VLP treatment, the authors went on to perform DNA microarray analysis to look at gene expression profiles in PBMC and macrophages treated with VLPs. The authors noticed induction of interferon (IFN), IFN-stimulated genes (ISIGs), cytokines like IL-10, IP-10, IL15, and most notably, IL-27. Thus, the anti-HIV effects seen with VLP treatment resulted from the release of suppressive factors following treatment of cells with HPV-VLPs. VLPinduced IL-27 expression and production in PBMC and macrophages was further confirmed and quantified using RT-PCR and ELISA, respectively. To tease out the specific role of IL-27 in suppression of HIV replication, the authors immunodepleted IL-27 from VLP-treated cell supernatants, and saw a significant reduction in the inhibition of HIV replication, indicating IL-27 secretion may be one factor contributing to the suppressive effects seen upon VLP treatment of HIV-infected cells. To confirm the direct effect of IL-27 on HIV replication, this study went on to treat cells with a recombinant IL-27 (rIL-27) dose response and showed increasing suppression of HIV replication in the presence of increasing rIL-27 doses. Furthermore, to determine the specificity of IL-27-mediated inhibition of HIV replication, the authors performed real-time RT-PCR to examine transcription of HIV RNA in the presence of IL-27. Results indicated a $60-80 \%$ decrease in HIV transcription in the presence of IL-27. Lastly, the authors performed DNA microarray analysis on PHA-stimulated CD4 + $\mathrm{T}$ cells in the presence or absence of IL-27 to compare gene induction profiles. Cells cultured 
in the presence of IL-27 showed significant upregulation of antiviral genes, including ISIGs, myxovirus resistance protein, and $2^{\prime}-5^{\prime}$-oligoadenylate synthetase.

Shortly after the initial discovery of the IL-27 anti-HIV functions, the same research group examined the mechanisms of IL-27 antiviral activity compared to those of IFN- $\alpha$, another key cytokine also known to inhibit HIV replication. In this study the activity and gene expression profiles of IL-27 and IFN- $\alpha$ were compared in human CD4 + T cells and macrophages (Imamichi, Yang et al., 2008). The authors performed a neutralization assay to define the role of IFN in IL-27-mediated inhibition of HIV replication. HIV-infected CD4 T cells and macrophages were treated with IL-27 in the presence/absence of an antibody cocktail containing neutralizing antibodies to each IFN. The antibody treatment did not affect HIV inhibition by IL-27, indicating that IFN is not an intermediate in the inhibition of HIV replication by IL-27. Of additional note, IL-27, like IFN- $\alpha$, preferentially inhibited HIV replication in macrophages compared to CD4 T cells, as lower doses of these cytokines were required to get complete inhibition of HIV replication in macrophages compared to T cells. Using DNA microarray analysis, this study went on to compare the gene expression profiles of IL-27 and IFN- $\alpha$ in CD4 T cells and macrophages. From this experiment it was noted that both cytokines induced a similar profile of ISIGs and antiviral genes, with greater antiviral gene induction in the macrophages compared to CD4 T cells upon IL-27 stimulation. Of particular note, IL-27 significantly upregulated antiviral genes like myxovirus resistance 1 (MX1), oligoadenylate synthetase 2 (OAS2), and RNA-dependent protein kinase-eukaryotic initiation factor 2a kinase (PKR/EIF2AK) by greater than 2-fold in the macrophage cells. Furthermore, IL-27 also induced expression of apolipoprotein B messenger RNA-editing enzyme-catalytic polypeptide-like 3G (APOBEC3G) in macrophages, but not in CD4 T cells. The APOBEC proteins are key host cell-derived protective molecules, acting as anti-HIV proteins that function as cytidine deaminases to interfere with viral replication (Romani, Engelbrecht et al., 2009). Taken together, these results indicate that IL-27, like IFN- $\alpha$, significantly induces multiple IFIGs and APOBEC3G in macrophages, resulting in the striking anti-HIV functions of these cytokines.

Subsequent to the initial studies on IL-27 functions in HIV infection, a separate research group set out to determine whether IL-27 directly or indirectly regulated expression of the APOBEC family of proteins (Greenwell-Wild, Vazquez et al., 2009). Since it had been previously shown that IFN- $\alpha$ could regulate expression of APOBEC, clinical trials commenced to explore the impact of IFN- $\alpha$ treatment on induction of APOBEC expression in the setting of HIV infection et (Neumann, Polis et al., 2007). However, the many negative side effects of IFN treatment led researchers to consider alternative mechanisms to induce APOBEC expression, in particular, mechanisms that minimize IFN toxicities associated with direct administration of this cytokine. Greenwell-Wild et al. (2009) showed that IL-27 could be a good alternative, as they showed IL-27 can induce APOBEC expression to curb HIV replication. This study attributed the anti-viral properties of IL-27 to the intermediary IL-27-induced IFN- $\alpha$, which can then, in turn, coordinate anti-viral responses. Interestingly, this study investigated whether other IL-12 cytokine family members, namely IL-12 and IL-23, could suppress HIV replication. No significant reduction in HIV replication was observed with IL-12 or IL-23 treatments, indicating that the inhibition of HIV replication was selective to IL-27 in the IL-12 family of cytokines. This study went on to examine the kinetics of IL-27-induced APOBEC expression and found a 24 hour delay in the induction of expression by real-time PCR, suggestive of an intermediary in the induction of APOBEC expression. Since it was previously known that IFN$\alpha$ could regulate APOBEC expression, IFN- $\alpha$ and IFN- $\beta$ became likely agents for the 
intermediary molecules mediating IL-27-induced APOBEC expression. Greenwell-Wild et al. (2009) went on to show IL-27 can induce expression of both IFN- $\alpha$ and $-\beta$, and that these IFNs alone could inhibit HIV replication (p24 assay). Lastly, to confirm that IL-27 induces APOBEC expression through IFN, they blocked the IFN- $\alpha / \beta$ receptor (IFNAR) with neutralizing antibody, followed with IL-27 stimulation, and found no induction of APOBEC expression, indicating IFN is an intermediate requirement in IL-27-induced APOBEC expression. Furthermore, when IFN and IL-27 were added in unison to cell cultures, enhanced inhibition of HIV replication was observed, pointing to additional antiviral mechanisms under the regulation of these cytokines. Taken together, this study illustrates teamwork between two cytokines, IFN and IL-27, in the suppression of HIV.

So far we have reviewed how IL-27 can suppress HIV replication; however, limited studies have described how HIV can affect IL-27. The first study to investigate the impact of HIV infection on IL-27 investigated how clinical characteristics such as viral load, hepatitis C virus (HCV) co-infection, and CD4 T cell counts were associated with changes in circulating levels of IL-27 (Guzzo, Hopman et al., 2010). Guzzo et al. (2010) observed a modest negative correlation between IL-27 levels and HIV viral load, suggesting that circulating HIV virus may suppress IL-27 expression, a potential pathogenic mechanism for the virus to limit host anti-viral responses. Additionally, in this study, when patients were grouped according to those receiving HAART therapy and those naïve to HAART, no difference was found in IL27 expression, illustrating no impact of HAART on IL-27 expression. Lastly, this study investigated if IL-27 expression was associated with changing CD4 T cell counts. A consistent trend was observed among patient groups, namely, IL-27 expression peaked with moderate declines in CD4 T cell counts (200-350), then decreased in the low CD4 T cell count $(<200)$ patients. The study authors hypothesized that the initial boost in IL-27 signified the host response to viral insult (declining CD4 T cells), as the host upregulates the anti-HIV cytokine as a protective response. However, as HIV disease progresses, dysregulated immune responses and increasing viral loads renders the host unable to produce adequate IL-27, and the observation of decreased IL-27 with low CD4 T cells counts was observed. Overall, this study suggested that HIV viral load, HCV co-infection, and CD4 T cell counts are strongly associated with changes in circulating levels IL-27 in the HIV-infected host. This research was the first to report how HIV infection might affect expression of IL-27, and to date, only one other study has investigated the effect of HIV on IL-27 expression (Palermo, Patterson et al., 2011). Palermo et al. (2011) performed alternative AIDS vaccine strategies in rhesus macaques followed by viral challenge with adenovirus-expressing HIV-env, SIV-gag, or SIV-nef proteins. Following vaccination and viral challenge, global transcriptional profiling was performed to characterize any significant alterations in gene expression. At the time of peak viremia in the animals, gene expression profiles of the immunized groups were different from that of controls. Of particular note was an upregulation of IL-27 expression in the immunized group, indicating the protective host response to virus is a boost in the antiviral cytokine, IL-27. This study reported significant differences in gene expression of a variety of immunological markers between treatment groups, suggesting new potential correlates of protection in HIV infection.

Taking into account the role of IL-27 in driving the differentiation of Th1 cells and keeping in mind the ability of IL-27 to inhibit HIV replication, it is clear that further understanding of the regulation of IL-27 expression and function during HIV infection is an important area of research. It is possible that the use of treatments that upregulate the expression of this 
cytokine may have a two-pronged beneficial effect: inhibition of virus replication and reinstating the Th1 CD4 T cell populations.

\section{IL-23 and HIV infection}

As discussed, the IL-12 family of cytokines regulates CD4 T cell development and immune responses. In particular, IL-23 is an IL-12 family member important in regulating the differentiation of the proinflammatory, IL-17-producing, Th17 cells. IL-23, a heterodimeric cytokine composed of covalently linked IL-12p40 and IL-23p19 subunits was originally discovered in 2000 and identified as a member of the IL-12-related cytokine family (Oppmann, Lesley et al., 2000). IL-23 is predominantly produced by activated myeloid cells such as activated monocytes, antigen-presenting cells, including dendritic cells and macrophages, T cells, B cells and endothelial cells (Oppmann, Lesley et al., 2000;Parham, Chirica et al., 2002; van Seventer, Nagai et al., 2002). IL-23 shares the IL-12p40 subunit with IL-12, and the IL-23-specific subunit, p19, forms a disulphide-linked heterodimer with the IL-12p40 subunit(Oppmann, Lesley et al., 2000). The high affinity IL-23 receptor complex is comprised of an IL-12R $\beta 1$ (as found in IL-12 receptor) and a unique IL-23Ra subunit (Parham, Chirica et al., 2002). As mentioned in the previous section on IL-12, many studies have shown the effect of HIV infection on the production of IL-12 and IL-12 receptor expression; there is strong evidence suggesting that IL-12 production is impaired in cells infected in vitro with HIV and in HIV positive patients (Chehimi, Starr et al., 1994; Marshall, Chehimiet al., 1999;Daftarian, Diaz-Mitoma et al., 1995;Boucher, Parato et al., 2010; Buisson, Benlahrech et al., 2009). Since IL-12 and IL-23 share the p40 subunit as well as the IL-12Rß1 receptor subunit, it is interesting to speculate on the impact of HIV on IL-23 function and the involvement of IL-23 in HIV pathogenesis.

The ability of immune cells to produce IL-23 during HIV infection has not been fully studied. Lee and colleagues were the first to demonstrate that spontaneously produced IL-23p19 and IFN- $\gamma$ mRNA from PBMC are reduced in HIV positive patients who exhibited increased CD4 T cell counts while on long term HAART (Lee, French, \& Price, 2004). The inability of the cells to produce "normal" levels of these key cytokines may compromise the immune response to opportunistic infections. A very recent study showed that LPS-induced IL-23 production by monocytes and dendritic cells from HIV positive patients was actually increased compared to HIV negative controls (Louis, Dutertre et al., 2010). This study included the first longitudinal analysis of IL-23 production during primary HIV infection. The authors found that the production of IL-23 was greatly increased and sustained during chronic infection. Interestingly, in response to simultaneous LPS and IFN-y treatment, they also found that IL-23 production, but not IL12 p70 production correlated strongly with viral loads. This study indicates that HIV induces the production of IL-23, and that IL-23 may have an important role in controlling viral infection. However, taken together, these studies have conflicting results. In the study by Lee et al., mRNA levels of p19 were examined whereas Louis et al. examined secreted IL-23, which may partially explain the observed discrepancy. In 2004, a study revealed that IL-23 has potent adjuvant effects on induction of epitope-specific cytotoxic T lymphocytes (CTLs) (Matsui, Moriya et al., 2004). The authors found that coadministration of an IL-23 expression plasmid in a prime-boost immunization enhanced the induction of Hepatitis $\mathrm{C}$ virus (HCV)-specific CTLs in mice. This finding suggests that 
IL-23 might offer a new prophylactic and therapeutic strategy for vaccine development against infectious pathogens.

To date, the mechanism of how HIV affects the production of IL-23 is still not clear. However, a few studies have been reported on the molecular mechanism of the inhibitory action of HIV on IL-12, a related cytokine sharing the IL-12p40 subunit and IL-12R $\beta 1$ receptor subunit with IL-23. An in vitro study showed that HIV infection of myeloid cells was able to disrupt MAP kinase activation and transcription factor binding to the IL-12p40 promoter(Chambers, Parks et al., 2004). This observation may be explained as a direct effect of HIV on the IL-12p40 promoter or may occur as a consequence of altered MAP kinase activation. Indeed, the authors demonstrated that the phosphorylation of JNK and p38 MAPK was impaired and the phosphorylation and degradation of IKBa was suppressed after HIV infection (Chambers, Parks, \& Angel, 2004). Another in vitro study found that intracellular Nef inhibits LPS-induced IL-12p40 transcription by inhibiting the JNKactivated NF-kB without affecting AP-1 activity (Ma, Mishra et al., 2009). This result suggests that intracellular Nef selectively inhibits $N F-\kappa B$ activity (apart from other transcription factors, such as AP-1), resulting in the inhibition of IL-12p40 expression. Similar studies on the molecular mechanism of IL-23p19 regulation in the context of HIV infection have yet to be published.

It is well known that IL-23 is important for the development of a proinflammatory subset of T cells, Th17. Little is known about how HIV modulates the function of IL-23 and how HIV affects the main downstream functions of this cytokine in the promotion of Th17 cells. If HIV infection decreases IL-23 production, Th17 expansion and activation may be downregulated. To date, no study has examined the correlation between IL-23 and the IL23/Th17 axis in HIV positive patients. Like IL-23, the roles of Th17 and IL-17 in HIVreplication and immunopathogenesis are not well understood. In the next section we will discuss the impact of HIV infection on Th17 cell regulation.

\section{Th17 cells and HIV infection}

The discovery of the Th17 subset has expanded our understanding of $\mathrm{T}$ cell mediated immunity, leading to a revision of the classical model of $\mathrm{T}$ cell populations. Th17 is a proinflammatory $\mathrm{T}$ cell population that is involved in host immune defense against pathogens not adequately handled by Th1 or Th2 cells. The Th17 subset is termed after its main effector proinflammatory cytokine, IL-17. The differentiation of Th17 subset is driven by the combination of TGF- $\beta$ and IL- 6 which upregulate the transcription factor RORyt (McGeachy, Chen et al., 2009). Th17 cells mediate inflammation through upregulation of chemokine and inflammatory cytokine expression, and recruitment of macrophages and neutrophils (Gaffen, Kramer et al., 2006;Korn, Bettelli et al., 2009). The inflammatory response is amplified by the presence of all these factors, resulting in a greater inflammation than the response from Th1/Th2 cells. Th17 cells have been demonstrated to be specifically involved in immunity against Toxoplasma gondii, Candida albicans, Klebsiella pneumoniae and Mycobacterium tuberculosis (Conti, Shen et al., 2009; Gaffen, Kramer, Yu, \& Shen, 2006; Korn, Bettelli, Oukka, \& Kuchroo, 2009). However a role for Th17 cells in the regulation of virus infection has been a recent focal area of research, particularly in the case of HIV.

Mucosal transmission of HIV is the main route of virus entry and site of initial virus infection. Th17 cells play important roles in the regulation of mucosal immunity, and they are found in 
high concentration in the lamina propria of the GI tract (Hunt, 2010). Th17 cells prevent microbial translocation across mucosal surfaces by enhancing expression of antimicrobial peptides and mobilizing neutrophils to infected sites. At the same time, gut-associated lymphoid tissue (GALT) is a major reservoir for CD4 T cells, the source of Th17 cells, and a key site of HIV replication and CD4 T cell loss (Brenchley, Schacker et al., 2004;Mehandru, Poles et al., 2004). Pathogenic SIV as well as HIV infection results in rapid and significant Th17 loss from the GALT which would be expected to have deleterious effects on the regulation of microbial translocation (Brenchley, Schacker et al., 2004; Raffatellu, Santos et al., 2008). Indeed, HIV infection is correlated with increases in microbial translocation and mucosal inflammation (Gori, Tincati et al., 2008). This is supported by studies showing that plasma LPS levels, considered as an indication of microbial translocation, in HIV infected individuals are remarkably higher than uninfected individuals (Jiang, Lederman et al., 2009;d'Ettorre, Paiardini et al., 2011). Interestingly, SIV infected rhesus macaques exhibited Th17 depletion in ileal mucosa, resulting in a compromised mucosal barrier and susceptibility to Salmonella infection compared to that observed in uninfected macaques (Raffatellu, Santos, et al., 2008). Furthermore, in the same study, IL-17R deficient mice also had increased systemic dissemination of Salmonella from the gut. Together, this suggests that IL-17 deficiency may lead to impaired mucosal barrier function. An interesting report on V $\delta 1 \mathrm{~T}$ cells, T cells present in mucosal tissues expressing the $\gamma \delta \mathrm{T}$ cell receptor, demonstrated that HIV positive individuals exhibited an expanded population of these cells that produced both IFN- $\gamma$ and IL17 (Fenoglio, Poggi et al., 2009). This is of interest to mucosal immunity and HIV, as circulating V81 T lymphocytes, resident cells in GALT, are increased in HIV-1 infection due to mucosal depletion and recirculation (Nilssen, Muller et al., 1996;Fenoglio, Poggi et al., 2009). Additionally, Fenoglio et al. (2009) showed that these cells were able to proliferate and produce IFN- $\gamma$ and IL-17 in response to C. albicans and that these cells expressed markers for a memory T cell phenotype as well as the Th17 transcription factor RORC. The elevation of this subset of $\mathrm{T}$ cells in the context of HIV infection may represent a possible mechanism to compensate for impaired CD4 T cells, and in particular, that of Th17.

Studies elucidating the relationship between Th17 cells and HIV infection have yielded inconclusive results. The first report that associated HIV with IL-17 showed an increase of IL-17 production by CD4 T cells in peripheral blood of HIV patients both in cells left untreated or stimulated with PMA/ionomycin (Maek, Buranapraditkun et al., 2007). It was later shown that HIV-1 infected children with a plasma viral load of below 50 copies $/ \mathrm{ml}$ (undetectable HIV) had enhanced IL-17 production in contrast to those with detectable HIV, which had no observable IL-17 production (Ndhlovu, Chapman et al., 2008). This suggested a possible impairment of Th17 cells in patients with detectable HIV levels and decreased IL17 levels, and that restoration of Th17 cells could be possible through suppression of viremia. In 2008, Macal et al. showed that CD4 T cell restoration (>50\%) could be achieved regardless of persistent proviral burden and previous HAART (Macal, Sankaran et al., 2008). This CD4 T cell restoration was associated with enhanced Th17 CD4 T cell accumulation. Additionally, HIV-1 and CMV specific IL-17 producing CD4 T cells are detectable in early HIV-1 infection, but are undetectable in chronic and non-progressive HIV-1 infection (Yue, Merchant et al., 2008). These experiments together suggest that IL-17 producing T cells are associated with viral load and disease progression. They also call into question of what impact the restoration of Th17 cells would have on the progression of HIV in the long run. If reconstitution is possible, increased Th17 levels may be beneficial in slowing the progression 
of the disease towards AIDS, in particular with regard to the function of these cells to control possible fungal, parasitic, and bacterial opportunistic infections.

It is unclear if Th17 cells are preferentially targeted by HIV for infection. One study suggested preferential targeting of CCR6+CCR5+ Th17 cells by CCR5 tropic viruses in vivo (El Hed, Khaitan et al., 2010). CCR4+ CCR6+ and CXCR3+ CCR6+ T cells express cytokines and transcription factors specific for Th17 and Th1/Th17 lineages respectively. These markers contribute to gut and lymph node homing potential. These two types of cells are highly permissive to HIV replication in that while their frequency is diminished, they can recruit more CCR6+ T cells into sites of viral replication (Gosselin, Monteiro et al., 2010). Similarly, in SIV infection, a4 $\beta 7$ hiCD4 memory T cells were found to harbour most Th17 cells and were significantly depleted (Kader, Wang et al., 2009). In SIV infected macaques, one group found that Th17 loss at mucosal surfaces predicted AIDS progression (Cecchinato, Trindade et al., 2008). Furthermore, there was a negative correlation between Th17 cell frequencies at mucosal sites and plasma virus level. Altogether these papers found that Th17 cells were preferentially depleted within a few weeks in HIV/SIV infection. Other reports show that Th17 cells may not be preferentially infected by HIV in vivo. Rather, CD4 T cell development was shown to be skewed away from the Th17 phenotype toward Th1 cell maturation in HIV patients (Brenchley, Paiardini et al., 2008) possibly leading to a significant loss of Th17 cells in the GI tract of HIV patients.

Although there is ample evidence to state that Th17 is important in HIV pathogenesis, it is still unclear how Th17 cells and IL-17 are regulated during HIV infection. Understanding how Th17 cells are dysregulated by HIV infection is crucial to restoring its population and function and it is possible that treatments designed to increase Th17 levels may be beneficial to HIV infection. This may be particularly important in the protection against opportunistic diseases, given that Th17 cells have been well characterized to protect against bacterial, parasitic, and fungal infections.

\section{Treg in HIV infection}

Treg cells function to prevent chronic immune activation and act in a suppressive manner to control immune activation. These cells are generally defined phenotypically as CD4, CD25+, and Foxp3+. It appears that within the setting of HIV infection, the Treg CD4 T cell population may be protective to the host by potentially suppressing HIV infection in conventional CD4 T cells as well as cytotoxic T cell activity (Moreno-Fernandez, Rueda et al., 2011;Kinter, McNally et al., 2007). The Treg population has been demonstrated to coordinate and maintain virusspecific immune responses (Rouse, Sarangi et al., 2006). Although Tregs have been shown to be infected by HIV, this may depend on the strain as well as host and viral properties. MorenoFernandez and colleagues (2009) demonstrated that X4 viruses exhibited a higher level of infection in Tregs at early time points compared to R5 viruses in Tregs and X4 viruses in effector T cells (Moreno-Fernandez, Zapata et al., 2009). A study which examined viral persistence in Treg cells found that these cells are preferentially targeted by HIV, as a greater number of Treg cells harboured more HIV DNA than non-Treg cells (Tran, de Goer de Herve MG et al., 2008). Of interest, the Foxp3 Treg transcription factor has been shown to enhance HIV gene expression via an NF- $\mathrm{B}$ dependent mechanism(Holmes, Knudsen et al., 2007). Additionally, HIV-specific Treg cells have been detected (Kared, Lelievre et al., 2008;Torheim, Ndhlovu et al., 2009). Indeed, HIV has been shown to bind to Treg cells via gp120/CD4 interactions which has been correlated with increased suppressive activities, extended Treg 
survival, and upregulated homing receptors for peripheral lymph nodes and mucosal lymphoid tissues (Ji \& Cloyd, 2009;Nilsson, Boasso et al., 2006). In the same study, it was shown that these Treg cells did not exhibit the same homing-induced apoptosis. Taken together, this suggests that the HIV-Treg interaction may contribute to upregulated levels of Tregs observed in lymphoid and mucosal compartments in HIV positive patients (Mozos, Garrido et al., 2007; Ji \& Cloyd, 2009; Nilsson, Boasso et al., 2006).

Absolute numbers of Treg and Treg frequency during HIV infection is an area of contention in this field. However, it has been demonstrated that the relative frequency of Treg cells within the CD4 T cell population as a whole appears to increase during HIV infection while at the same time, the absolute numbers of Tregs decline(Schulze Zur, Thomssen et al., 2011). This is supported by several studies which indicated a gradual decline in Treg absolute numbers during HIV pathogenesis (Jiao, Fu et al., 2009; Prendergast, Prado et al., 2010; Thorborn, Pomeroy et al., 2010; Cao, Jamieson et al., 2009). In particular, in primary HIV infection in untreated individuals, HIV-specific Treg cells and suppressive activity decreased over a 24 month follow-up period (Kared, Lelievre et al., 2008). Interestingly, a recent study by Weis et al. (2010) demonstrated that Treg cells were able to control immune activation in patients on ART, however this control was lost during interruption of ART, an observation attributed to the decline in absolute Treg numbers(Weiss, Piketty et al., 2010). Immune activation during HIV infection has been linked to HIV progression and negative outcomes during HIV infection (Douek, 2003; Kassiotis \& O'Garra, 2008; Lawn, Butera et al., 2001; Terzieva, 2008). Tregs could be protective as they can control this immune hyperactivation especially during chronic infection (Fazekas de St \& Landay, 2008; Belkaid \& Rouse, 2005). On the other hand, excess Treg activity results in "over" suppression of immune responses resulting in too much immune suppression, leading to faster HIV progression and negative outcomes (Kinter, Horak et al., 2007). This point is also supported by a report showing that recombinant IL-2 treatment in a phase III trial actually enhanced Treg populations, possibly explaining why this treatment failed to elicit better clinical outcome (Weiss, Letimier et al., 2010). Treg depletion has been associated with an increase in immune activation (Eggena, Barugahare et al., 2005) and several important studies have demonstrated correlation of Treg proliferation and turnover with lower CD4 counts (Bi, Suzuki et al., 2009; Piconi, Trabattoni et al., 2010; Xing, Fu et al., 2010).

Interestingly, elite controllers, a rare population of individuals that can maintain undetectable HIV viral loads in the absence of HAART, demonstrated higher frequencies of Treg cells compared to individuals on HAART (Chase, Yang et al., 2008). On the other hand, Owen et al., showed that individuals on HAART had higher frequencies of Tregs compared to elite controllers (Owen, Heitman et al., 2010). In contrast yet again, more recent studies have demonstrated that elite controllers have a lower level of Treg cells compared to viremic individuals, but that this "low" level of Tregs is similar to that observed in HIV positive individuals with viral load controlled by HAART (Brandt, Benfield et al., 2011). In support of this, another group demonstrated that elite controllers had an even lower Treg frequency than HIV negative individuals (Hunt, Landay et al., 2011). In view of these studies it seems that the Treg frequency in elite controllers may vary according to the patient group examined and to which group the comparison is being made.

\section{Th17 versus Treg in HIV infection}

Since the main function of Th17 is to mediate inflammatory responses, and it is involved in autoimmune diseases, it is prudent that the response is kept under control to avoid damage 
to host tissue. Treg development is inexorably associated with Th17 development. IL-2, an important growth factor for $\mathrm{T}$ cells, is one of several cytokines that mediates the balance between Th17 and Tregs. In vitro, levels of Th17 were reduced in the presence of IL-2, while Treg numbers increased with IL-2 stimulation (Stockinger, 2007). The same is true with respect to HIV infection; a recent study demonstrated that administration of IL-2 to HIV patients on ART resulted in enhanced levels of CD4 T cells and Treg cells (Ndhlovu, Sinclair et al., 2010b). Overall enhancement of the CD4 T cell count was attributed to enhanced levels of naïve $\mathrm{T}$ cells. At the same time, this resulted in a decrease in Th17 cell frequency, although the absolute numbers of Th17 did not change. These results suggest then that IL-2 is important for driving the differentiation of CD4 $\mathrm{T}$ cells and is selective for Treg development while not affecting levels of Th17 cells already present.

As mentioned before, TGF- $\beta$ function straddles the border between Treg and Th17 differentiation depending on the presence of IL-6. It is suggested that TGF- $\beta$ is constitutively produced by the resting immune system to induce Tregs to limit the effect of activated memory T cells (Korn, Bettelli, Oukka, \& Kuchroo, 2009). However, in the event that the immune system is triggered, IL-6 is induced to inhibit the production of Tregs and cause a switch towards Th17 development (Korn, Bettelli, Oukka, \& Kuchroo, 2009). This supports the claim that both TGF- $\beta$ and IL- 6 must be present for Th17 differentiation. The parallel use of TGF- $\beta$ in both Treg and Th17 subsets may be important in mediating the balance between the two. It has been suggested that Th17 and Treg share a reciprocal relationship (Bettelli, Carrier et al, 2006; Mucida, Park et al., 2007; Zhou, Lopes et al., 2008; Quintana, Basso et al., 2008). It has been shown that the observed rapid Th17 decline in acute HIV infection is predictive of the immune activation later seen in chronic infection. These studies also observed a loss of the Th17/Treg balance in pathogenic SIV infection (Lederer, Favre et al., 2009). More recently, Prendergast et al (2010) demonstrated a profound loss of Th17 cells before advanced disease, in contrast to a gradual decline of Treg cells (Prendergast, Prado et $\mathrm{al}$, 2010). In a recent review, B. Kanwar et al. suggest that it is the relative balance of these two subsets of T cells that is key to the regulation of progression of HIV/AIDS, as opposed to considering only the specific functions of either subset alone(Kanwar, Favre et al., 2010). Future work in this regard will be key to furthering our understanding of the impact of this virus on our immune system.

\section{The "other" subsets: Th2, Th9, Tfh}

As discussed above, clearly HIV infection impacts the function of Th1, Th17, and Treg cells. The antibody response supported by the Th2 T cell subset is critically important to anti-HIV immune responses, however the scope of this topic fell outside the realm of this chapter. Currently little is known about the impact of HIV infection on the development and function of Th9 and Tfh cells. It is interesting to speculate that the differentiation programming and functional effects of these cells are disrupted during infection and warrant further research in this regard.

\section{Conclusion}

In Figure 2, the overall effect of HIV infection on Th cell subset is illustrated. In actuality, it is likely that the mechanisms and impact of the virus on these cells is much more complex than portrayed here, however this diagram summarizes the general outcome of CD4 T cell 
differentiation in terms of Th1, Treg, and Th17 cells during HIV infection. Our immune systems consist of many complex processes that are interconnected and the effect of inhibiting or upregulating particular cell types will affect not only that particular cell type, but a multitude of other cells and cellular processes. As we further our understanding of HIV infection and HAART on the regulation of the differentiation of the CD4 $\mathrm{T}$ cell response, this will enhance our ability to design new treatment therapeutics and potential vaccine targets.

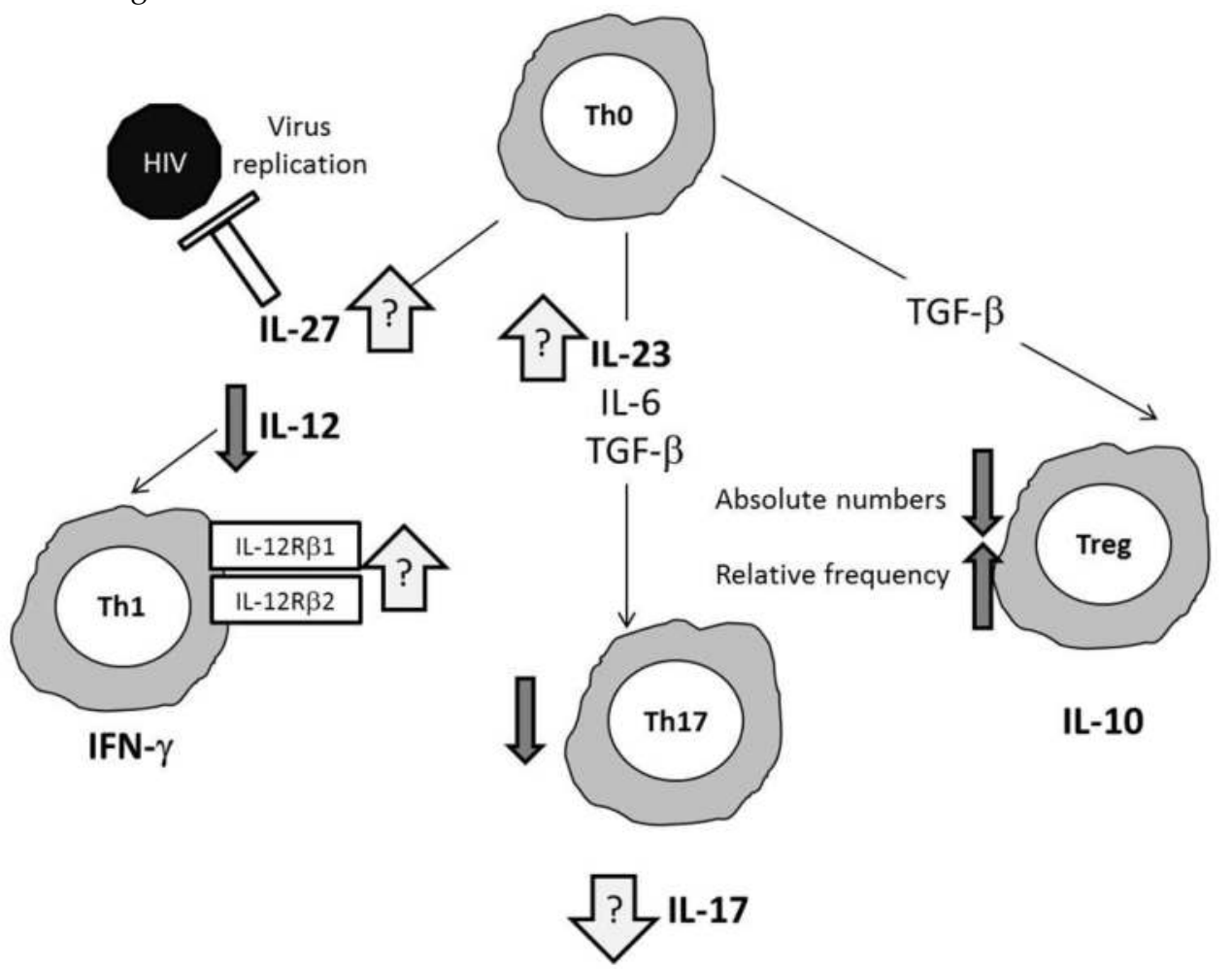

Fig. 2. Impact of HIV infection on the IL-12 family of cytokines and their respective effects on CD4 T cell development. Shown are the T helper (Th) subsets discussed in detail in this chapter. Cytokines that induce their differentiation are shown preceding the cell type, and effector cytokines are listed below each cell type. Dark arrows indicate well-defined increases (up arrow) or decreases (down arrows) in cytokines (IL-12) or Th cells (Th17 and Treg). Large arrows with question marks indicate increases (up arrows) or decreases (down arrow) in cytokine and receptor expression that are not well defined. Shown in the top left is the ability of IL-27 to inhibit HIV replication.

\section{References}

Alber, G., Al-Robaiy, S., Kleinschek, M., Knauer, J., Krumbholz, P., Richter, J., Schoeneberger, S., Schuetze, N., Schulz, S., Toepfer, K., Voigtlaender, R., Lehmann, 
J., and Mueller, U. (2006). Induction of immunity and inflammation by interleukin12 family members. Ernst.Schering.Res.Found.Workshop. 107-127.

Belkaid, Y. and Rouse, B. T. (2005). Natural regulatory T cells in infectious disease. Nat Immunol. 6, 353-360.

Bettelli, E., Carrier, Y., Gao, W., Korn, T., Strom, T. B., Oukka, M., Weiner, H. L., and Kuchroo, V. K. (2006). Reciprocal developmental pathways for the generation of pathogenic effector TH17 and regulatory T cells. Nature 441, 235-238.

Bi, X., Suzuki, Y., Gatanaga, H., and Oka, S. (2009). High frequency and proliferation of CD4+ FOXP3+ Treg in HIV-1-infected patients with low CD4 counts. Eur.J.Immunol. 39, 301-309.

Boucher, J. G., Parato, K. A., Frappier, F., Fairman, P., Busca, A., Saxena, M., Blahoianu, M. A., Ma, W., Gajanayaka, N., Parks, R. J., Kumar, A., and Angel, J. B. (2010). Disparate regulation of LPS-induced MAPK signaling and IL-12p40 expression between different myeloid cell types with and without HIV infection. Viral Immunol. 23, 17-28.

Boyer, J. D., Robinson, T. M., Kutzler, M. A., Parkinson, R., Calarota, S. A., Sidhu, M. K., Muthumani, K., Lewis, M., Pavlakis, G., Felber, B., and Weiner, D. (2005). SIV DNA vaccine co-administered with IL-12 expression plasmid enhances CD8 SIV cellular immune responses in cynomolgus macaques. J.Med.Primatol. 34, 262-270.

Brandt, L., Benfield, T., Mens, H., Clausen, L. N., Katzenstein, T. L., Fomsgaard, A., and Karlsson, I. (2011). Low level of regulatory T-cells and maintenance of balance between regulatory T-cells and TH17 cells in HIV-1-infected Elite Controllers. J.Acquir.Immune.Defic.Syndr.

Brenchley, J. M., Paiardini, M., Knox, K. S., Asher, A. I., Cervasi, B., Asher, T. E., Scheinberg, P., Price, D. A., Hage, C. A., Kholi, L. M., Khoruts, A., Frank, I., Else, J., Schacker, T., Silvestri, G., and Douek, D. C. (2008). Differential Th17 CD4 T-cell depletion in pathogenic and nonpathogenic lentiviral infections. Blood. 112, 2826-2835.

Brenchley, J. M., Schacker, T. W., Ruff, L. E., Price, D. A., Taylor, J. H., Beilman, G. J., Nguyen, P. L., Khoruts, A., Larson, M., Haase, A. T., and Douek, D. C. (2004). CD4+ $\mathrm{T}$ cell depletion during all stages of HIV disease occurs predominantly in the gastrointestinal tract. J.Exp.Med. \%20;200, 749-759.

Buisson, S., Benlahrech, A., Gazzard, B., Gotch, F., Kelleher, P., and Patterson, S. (2009). Monocyte-derived dendritic cells from HIV type 1-infected individuals show reduced ability to stimulate $\mathrm{T}$ cells and have altered production of interleukin (IL)12 and IL-10. J.Infect.Dis. 199, 1862-1871.

Cao, W., Jamieson, B. D., Hultin, L. E., Hultin, P. M., and Detels, R. (2009). Regulatory T cell expansion and immune activation during untreated HIV type 1 infection are associated with disease progression. AIDS Res.Hum.Retroviruses. 25, 183-191.

Cecchinato, V., Trindade, C. J., Laurence, A., Heraud, J. M., Brenchley, J. M., Ferrari, M. G., Zaffiri, L., Tryniszewska, E., Tsai, W. P., Vaccari, M., Parks, R. W., Venzon, D., Douek, D. C., O'Shea, J. J., and Franchini, G. (2008). Altered balance between Th17 and Th1 cells at mucosal sites predicts AIDS progression in simian immunodeficiency virus-infected macaques. Mucosal.Immunol. 1, 279-288.

Chambers, K. A., Parks, R. J., and Angel, J. B. (2004). Disruption of MAP kinase activation and nuclear factor binding to the IL-12 p40 promoter in HIV-infected myeloid cells. Clin.Exp.Immunol. 137, 329-340.

Chase, A. J., Yang, H. C., Zhang, H., Blankson, J. N., and Siliciano, R. F. (2008). Preservation of FoxP3+ regulatory $\mathrm{T}$ cells in the peripheral blood of human immunodeficiency 
virus type 1-infected elite suppressors correlates with low CD4+ T-cell activation. J.Virol. 82, 8307-8315.

Chehimi, J., Starr, S. E., Frank, I., D'Andrea, A., Ma, X., MacGregor, R. R., Sennelier, J., and Trinchieri, G. (1994). Impaired interleukin 12 production in human immunodeficiency virus-infected patients. J.Exp.Med. 179, 1361-1366.

Chong, S. Y., Egan, M. A., Kutzler, M. A., Megati, S., Masood, A., Roopchard, V., Garcia-Hand, D., Montefiori, D. C., Quiroz, J., Rosati, M., Schadeck, E. B., Boyer, J. D., Pavlakis, G. N., Weiner, D. B., Sidhu, M., Eldridge, J. H., and Israel, Z. R. (2007). Comparative ability of plasmid IL-12 and IL-15 to enhance cellular and humoral immune responses elicited by a SIVgag plasmid DNA vaccine and alter disease progression following $\operatorname{SHIV}(89.6 \mathrm{P})$ challenge in rhesus macaques. Vaccine 25, 4967-4982.

Conti, H. R., Shen, F., Nayyar, N., Stocum, E., Sun, J. N., Lindemann, M. J., Ho, A. W., Hai, J. H., Yu, J. J., Jung, J. W., Filler, S. G., Masso-Welch, P., Edgerton, M., and Gaffen, S. L. (2009). Th17 cells and IL-17 receptor signaling are essential for mucosal host defense against oral candidiasis. J.Exp.Med. 206, 299-311.

Crotty, S. (2011). Follicular Helper CD4 T Cells (T(FH)). Annu.Rev.Immunol. 29:621-63., 621663.

d'Ettorre, G., Paiardini, M., Zaffiri, L., Andreotti, M., Ceccarelli, G., Rizza, C., Indinnimeo, M., Vella, S., Mastroianni, C. M., Silvestri, G., and Vullo, V. (2011). HIV Persistence in the Gut Mucosa of HIV-Infected Subjects Undergoing Antiretroviral Therapy Correlates with Immune Activation and Increased Levels of LPS. Curr.HIV.Res.

Daftarian, M. P., Diaz-Mitoma, F., Creery, W. D., Cameron, W., and Kumar, A. (1995). Dysregulated production of interleukin-10 (IL-10) and IL-12 by peripheral blood lymphocytes from human immunodeficiency virus-infected individuals is associated with altered proliferative responses to recall antigens. Clin.Diagn.Lab Immunol. 2, 712-718.

de Arquer, G. R., Pena, R., Cabrera, C., Coma, G., Ruiz-Hernandez, R., Guerola, R., Clotet, B., Ruiz, L., Este, J. A., Calle, M. L., and Bofill, M. (2007). Skewed expression and up-regulation of the IL-12 and IL-18 receptors in resting and activated CD4 T cells from HIV-1-infected patients. J.Leukoc.Biol. 82, 72-78.

Ding, C., Xu, J., and Li, J. (2008). ABT-874, a fully human monoclonal anti-IL-12/IL-23 antibody for the potential treatment of autoimmune diseases. Curr. Opin. Investig. Drugs 9, 515-522.

Douek, D. C. (2003). Disrupting T-cell homeostasis: how HIV-1 infection causes disease. AIDS Rev. 5, 172-177.

Egan, M. A., Chong, S. Y., Megati, S., Montefiori, D. C., Rose, N. F., Boyer, J. D., Sidhu, M. K., Quiroz, J., Rosati, M., Schadeck, E. B., Pavlakis, G. N., Weiner, D. B., Rose, J. K., Israel, Z. R., Udem, S. A., and Eldridge, J. H. (2005). Priming with plasmid DNAs expressing interleukin-12 and simian immunodeficiency virus gag enhances the immunogenicity and efficacy of an experimental AIDS vaccine based on recombinant vesicular stomatitis virus. AIDS Res.Hum.Retroviruses 21, 629-643.

Eggena, M. P., Barugahare, B., Jones, N., Okello, M., Mutalya, S., Kityo, C., Mugyenyi, P., and Cao, H. (2005). Depletion of regulatory T cells in HIV infection is associated with immune activation. J.Immunol. 174, 4407-4414.

El Hed, A., Khaitan, A., Kozhaya, L., Manel, N., Daskalakis, D., Borkowsky, W., Valentine, F., Littman, D. R., and Unutmaz, D. (2010). Susceptibility of human Th17 cells to human immunodeficiency virus and their perturbation during infection. J.Infect.Dis. 201, 843-854. 
Elson, C. O., Cong, Y., Weaver, C. T., Schoeb, T. R., McClanahan, T. K., Fick, R. B., and Kastelein, R. A. (2007). Monoclonal anti-interleukin 23 reverses active colitis in a T cell-mediated model in mice. Gastroenterology 132, 2359-2370.

Fakruddin, J. M., Lempicki, R. A., Gorelick, R. J., Yang, J., Adelsberger, J. W., Garcia-Pineres, A. J., Pinto, L. A., Lane, H. C., and Imamichi, T. (2007). Noninfectious papilloma virus-like particles inhibit HIV-1 replication: implications for immune control of HIV-1 infection by IL-27. Blood 109, 1841-1849.

Favre, D., Lederer, S., Kanwar, B., Ma, Z. M., Proll, S., Kasakow, Z., Mold, J., Swainson, L., Barbour, J. D., Baskin, C. R., Palermo, R., Pandrea, I., Miller, C. J., Katze, M. G., and McCune, J. M. (2009). Critical loss of the balance between Th17 and T regulatory cell populations in pathogenic SIV infection. PLoS.Pathog. 5, e1000295.

Fazekas de St, G. B. and Landay, A. L. (2008). Regulatory T cells in HIV infection: pathogenic or protective participants in the immune response? AIDS. 22, 671-683.

Fenoglio, D., Poggi, A., Catellani, S., Battaglia, F., Ferrera, A., Setti, M., Murdaca, G., and Zocchi, M. R. (2009). Vdelta1 T lymphocytes producing IFN-gamma and IL-17 are expanded in HIV-1-infected patients and respond to Candida albicans. Blood. 113, 6611-6618.

Gaffen, S. L., Kramer, J. M., Yu, J. J., and Shen, F. (2006). The IL-17 cytokine family. Vitam.Horm. 74:255-82., 255-282.

Gori, A., Tincati, C., Rizzardini, G., Torti, C., Quirino, T., Haarman, M., Ben Amor, K., van Schaik, J., Vriesema, A., Knol, J., Marchetti, G., Welling, G., and Clerici, M. (2008). Early impairment of gut function and gut flora supporting a role for alteration of gastrointestinal mucosa in human immunodeficiency virus pathogenesis. J.Clin.Microbiol. 46, 757-758.

Gosselin, A., Monteiro, P., Chomont, N., Diaz-Griffero, F., Said, E. A., Fonseca, S., Wacleche, V., El Far, M., Boulassel, M. R., Routy, J. P., Sekaly, R. P., and Ancuta, P. (2010). Peripheral blood CCR4+CCR6+ and CXCR3+CCR6+CD4+ T cells are highly permissive to HIV-1 infection. J.Immunol. 184, 1604-1616.

Gottlieb, A. B., Cooper, K. D., McCormick, T. S., Toichi, E., Everitt, D. E., Frederick, B., Zhu, Y., Pendley, C. E., Graham, M. A., and Mascelli, M. A. (2007). A phase 1, doubleblind, placebo-controlled study evaluating single subcutaneous administrations of a human interleukin-12/23 monoclonal antibody in subjects with plaque psoriasis. Curr.Med.Res.Opin. 23, 1081-1092.

Greenwell-Wild, T., Vazquez, N., Jin, W., Rangel, Z., Munson, P. J., and Wahl, S. M. (2009). Interleukin-27 inhibition of HIV-1 involves an intermediate induction of type I interferon. Blood. 114, 1864-1874.

Guzzo, C., Che Mat, N. F., and Gee, K. (2010). Interleukin-27 induces a STAT1/3 and NFkappaB dependent proinflammatory cytokine profile in human monocytes. J.Biol.Chem.

Guzzo, C., Hopman, W. M., Mat, N. F., Wobeser, W., and Gee, K. (2010). Impact of HIV infection, highly active antiretroviral therapy, and hepatitis $\mathrm{C}$ coinfection on serum interleukin-27. AIDS. 24, 1371-1374.

Hirao, L. A., Wu, L., Khan, A. S., Hokey, D. A., Yan, J., Dai, A., Betts, M. R., Draghia-Akli, R., and Weiner, D. B. (2008). Combined effects of IL-12 and electroporation enhances the potency of DNA vaccination in macaques. Vaccine. 26, 3112-3120.

Holmes, D., Knudsen, G., Mackey-Cushman, S., and Su, L. (2007). FoxP3 enhances HIV-1 gene expression by modulating NFkappaB occupancy at the long terminal repeat in human T cells. J.Biol.Chem. 282, 15973-15980. 
Hsieh, C. S., Macatonia, S. E., Tripp, C. S., Wolf, S. F., O'Garra, A., and Murphy, K. M. (1993). Development of TH1 CD4+ T cells through IL-12 produced by Listeria-induced macrophages. Science. 260, 547-549.

Hunt, P. W. (2010). Th17, gut, and HIV: therapeutic implications. Curr.Opin.HIV.AIDS. 5, 189-193.

Hunt, P. W., Landay, A. L., Sinclair, E., Martinson, J. A., Hatano, H., Emu, B., Norris, P. J., Busch, M. P., Martin, J. N., Brooks, C., McCune, J. M., and Deeks, S. G. (2011). A low $\mathrm{T}$ regulatory cell response may contribute to both viral control and generalized immune activation in HIV controllers. PLoS.One. 6, e15924.

Hunter, C. A. (2005). New IL-12-family members: IL-23 and IL-27, cytokines with divergent functions. Nat.Rev.Immunol. 5, 521-531.

Imamichi, T., Yang, J., Huang, D. W., Brann, T. W., Fullmer, B. A., Adelsberger, J. W., Lempicki, R. A., Baseler, M. W., and Lane, H. C. (2008). IL-27, a novel anti-HIV cytokine, activates multiple interferon-inducible genes in macrophages. AIDS 22, 39-45.

Ji, J. and Cloyd, M. W. (2009). HIV-1 binding to CD4 on CD4+CD25+ regulatory T cells enhances their suppressive function and induces them to home to, and accumulate in, peripheral and mucosal lymphoid tissues: an additional mechanism of immunosuppression. Int.Immunol. 21, 283-294.

Jiang, W., Lederman, M. M., Hunt, P., Sieg, S. F., Haley, K., Rodriguez, B., Landay, A., Martin, J., Sinclair, E., Asher, A. I., Deeks, S. G., Douek, D. C., and Brenchley, J. M. (2009). Plasma levels of bacterial DNA correlate with immune activation and the magnitude of immune restoration in persons with antiretroviral-treated HIV infection. J.Infect.Dis. 199, 1177-1185.

Jiao, Y., Fu, J., Xing, S., Fu, B., Zhang, Z., Shi, M., Wang, X., Zhang, J., Jin, L., Kang, F., Wu, H., and Wang, F. S. (2009). The decrease of regulatory T cells correlates with excessive activation and apoptosis of CD8+ T cells in HIV-1-infected typical progressors, but not in long-term non-progressors. Immunology. 128, e366-e375.

Jones, M. L., Young, J. M., Huang, Q. R., Puls, R. L., Webber, C. A., and Benson, E. M. (2003). Interleukin 12-augmented T cell proliferation of peripheral blood mononuclear cells from HIV-seropositive individuals is associated with interleukin 12 receptor beta 2 upregulation. AIDS Res.Hum.Retroviruses. 19, 283-292.

Kader, M., Wang, X., Piatak, M., Lifson, J., Roederer, M., Veazey, R., and Mattapallil, J. J. (2009). Alpha4(+)beta7(hi)CD4(+) memory T cells harbor most Th-17 cells and are preferentially infected during acute SIV infection. Mucosal.Immunol. 2, 439-449.

Kalliolias, G. D. and Ivashkiv, L. B. (2008). IL-27 activates human monocytes via STAT1 and suppresses IL-10 production but the inflammatory functions of IL-27 are abrogated by TLRs and p38. J.Immunol. 180, 6325-6333.

Kanwar, B., Favre, D., and McCune, J. M. (2010). Th17 and regulatory T cells: implications for AIDS pathogenesis. Curr.Opin.HIV.AIDS. 5, 151-157.

Kaplan, M. H., Schindler, U., Smiley, S. T., and Grusby, M. J. (1996). Stat6 is required for mediating responses to IL-4 and for development of Th2 cells. Immunity. 4, 313-319.

Kared, H., Lelievre, J. D., Donkova-Petrini, V., Aouba, A., Melica, G., Balbo, M., Weiss, L., and Levy, Y. (2008). HIV-specific regulatory T cells are associated with higher CD4 cell counts in primary infection. AIDS. 22, 2451-2460.

Kassiotis, G. and O'Garra, A. (2008). Immunology. Immunity benefits from a little suppression. Science. 320, 1168-1169. 
Kinter, A., McNally, J., Riggin, L., Jackson, R., Roby, G., and Fauci, A. S. (2007). Suppression of HIV-specific T cell activity by lymph node CD25+ regulatory T cells from HIVinfected individuals. Proc.Natl.Acad.Sci.U.S.A. 104, 3390-3395.

Kinter, A. L., Horak, R., Sion, M., Riggin, L., McNally, J., Lin, Y., Jackson, R., O'shea, A., Roby, G., Kovacs, C., Connors, M., Migueles, S. A., and Fauci, A. S. (2007). CD25+ regulatory $\mathrm{T}$ cells isolated from $\mathrm{HIV}$-infected individuals suppress the cytolytic and nonlytic antiviral activity of HIV-specific CD8+ $\mathrm{T}$ cells in vitro. AIDS Res.Hum.Retroviruses. 23, 438-450.

Korn, T., Bettelli, E., Oukka, M., and Kuchroo, V. K. (2009). IL-17 and Th17 Cells. Annu.Rev.Immunol. 27:485-517., 485-517.

Krueger, G. G., Langley, R. G., Leonardi, C., Yeilding, N., Guzzo, C., Wang, Y., Dooley, L. T., and Lebwohl, M. (2007). A human interleukin-12/23 monoclonal antibody for the treatment of psoriasis. N.Engl.J.Med. 356, 580-592.

Kurata, H., Lee, H. J., O'Garra, A., and Arai, N. (1999). Ectopic expression of activated Stat6 induces the expression of Th2-specific cytokines and transcription factors in developing Th1 cells. Immunity. 11, 677-688.

Landay, A. L., Clerici, M., Hashemi, F., Kessler, H., Berzofsky, J. A., and Shearer, G. M. (1996). In vitro restoration of $\mathrm{T}$ cell immune function in human immunodeficiency virus-positive persons: effects of interleukin (IL)-12 and anti-IL-10. J.Infect.Dis. 173, 1085-1091.

Larousserie, F., Charlot, P., Bardel, E., Froger, J., Kastelein, R. A., and Devergne, O. (2006). Differential effects of IL-27 on human B cell subsets. J.Immunol. 176, 5890-5897.

Lawn, S. D., Butera, S. T., and Folks, T. M. (2001). Contribution of immune activation to the pathogenesis and transmission of human immunodeficiency virus type 1 infection. Clin.Microbiol.Rev. 14, 753-77, table.

Lederer, S., Favre, D., Walters, K. A., Proll, S., Kanwar, B., Kasakow, Z., Baskin, C. R., Palermo, R., McCune, J. M., and Katze, M. G. (2009). Transcriptional profiling in pathogenic and non-pathogenic SIV infections reveals significant distinctions in kinetics and tissue compartmentalization. PLoS.Pathog. 5, e1000296.

Lee, S., French, M. A., and Price, P. (2004). IL-23 and IFN-gamma deficiency in immunodeficient HIV patients who achieved a long-term increase in CD4 T-cell counts on highly active antiretroviral therapy. AIDS. 18, 1337-1340.

Louis, S., Dutertre, C. A., Vimeux, L., Fery, L., Henno, L., Diocou, S., Kahi, S., Deveau, C., Meyer, L., Goujard, C., and Hosmalin, A. (2010). IL-23 and IL-12p70 production by monocytes and dendritic cells in primary HIV-1 infection. J.Leukoc.Biol. 87, 645-653.

Lucas, S., Ghilardi, N., Li, J., and de Sauvage, F. J. (2003). IL-27 regulates IL-12 responsiveness of naive CD4+ $\mathrm{T}$ cells through Stat1-dependent and -independent mechanisms. Proc.Natl.Acad.Sci.U.S.A 100, 15047-15052.

Ma, C. S., Tangye, S. G., and Deenick, E. K. (2010). Human Th9 cells: inflammatory cytokines modulate IL-9 production through the induction of IL-21. Immunol Cell Biol. 88, 621-623.

Ma, W., Mishra, S., Gajanayaka, N., Angel, J. B., and Kumar, A. (2009). HIV-1 Nef inhibits lipopolysaccharide-induced IL-12p40 expression by inhibiting JNK-activated NFkappaB in human monocytic cells. J.Biol.Chem. \%20;284, 7578-7587.

Macal, M., Sankaran, S., Chun, T. W., Reay, E., Flamm, J., Prindiville, T. J., and Dandekar, S. (2008). Effective CD4+ T-cell restoration in gut-associated lymphoid tissue of HIVinfected patients is associated with enhanced Th17 cells and polyfunctional HIVspecific T-cell responses. Mucosal.Immunol. 1, 475-488. 
Maek, A. N., Buranapraditkun, S., Klaewsongkram, J., and Ruxrungtham, K. (2007). Increased interleukin-17 production both in helper T cell subset Th17 and CD4-negative T cells in human immunodeficiency virus infection. Viral Immunol 20, 66-75.

Mangan, P. R., Harrington, L. E., O'Quinn, D. B., Helms, W. S., Bullard, D. C., Elson, C. O., Hatton, R. D., Wahl, S. M., Schoeb, T. R., and Weaver, C. T. (2006). Transforming growth factor-beta induces development of the $\mathrm{T}(\mathrm{H}) 17$ lineage. Nature 441, 231-234.

Marshall, J. D., Chehimi, J., Gri, G., Kostman, J. R., Montaner, L. J., and Trinchieri, G. (1999). The interleukin-12-mediated pathway of immune events is dysfunctional in human immunodeficiency virus-infected individuals. Blood 94, 1003-1011.

Matsui, M., Moriya, O., Belladonna, M. L., Kamiya, S., Lemonnier, F. A., Yoshimoto, T., and Akatsuka, T. (2004). Adjuvant activities of novel cytokines, interleukin-23 (IL-23) and IL-27, for induction of hepatitis $C$ virus-specific cytotoxic $T$ lymphocytes in HLA-A*0201 transgenic mice. J.Virol. 78, 9093-9104.

McGeachy, M. J., Chen, Y., Tato, C. M., Laurence, A., Joyce-Shaikh, B., Blumenschein, W. M., McClanahan, T. K., O'Shea, J. J., and Cua, D. J. (2009). The interleukin 23 receptor is essential for the terminal differentiation of interleukin 17-producing effector $\mathrm{T}$ helper cells in vivo. Nat.Immunol. 10, 314-324.

Mehandru, S., Poles, M. A., Tenner-Racz, K., Horowitz, A., Hurley, A., Hogan, C., Boden, D., Racz, P., and Markowitz, M. (2004). Primary HIV-1 infection is associated with preferential depletion of CD4+ $\mathrm{T}$ lymphocytes from effector sites in the gastrointestinal tract. J.Exp.Med. \%20;200, 761-770.

Moreno-Fernandez, M. E., Rueda, C. M., Rusie, L. K., and Chougnet, C. A. (2011). Regulatory $\mathrm{T}$ cells control HIV replication in activated $\mathrm{T}$ cells through a cAMPdependent mechanism. Blood.

Moreno-Fernandez, M. E., Zapata, W., Blackard, J. T., Franchini, G., and Chougnet, C. A. (2009). Human regulatory T cells are targets for human immunodeficiency Virus (HIV) infection, and their susceptibility differs depending on the HIV type 1 strain. J.Virol. 83, 12925-12933.

Mozos, A., Garrido, M., Carreras, J., Plana, M., Diaz, A., Alos, L., Campo, E., Garcia, F., and Martinez, A. (2007). Redistribution of FOXP3-positive regulatory T cells from lymphoid tissues to peripheral blood in HIV-infected patients. J.Acquir.Immune.Defic.Syndr. 46, 529-537.

Mucida, D., Park, Y., Kim, G., Turovskaya, O., Scott, I., Kronenberg, M., and Cheroutre, H. (2007). Reciprocal TH17 and regulatory T cell differentiation mediated by retinoic acid. Science. 317, 256-260.

Murai, M., Krause, P., Cheroutre, H., and Kronenberg, M. (2010). Regulatory T-cell stability and plasticity in mucosal and systemic immune systems. Mucosal.Immunol. 3, 443-449.

Ndhlovu, L. C., Chapman, J. M., Jha, A. R., Snyder-Cappione, J. E., Pagan, M., Leal, F. E., Boland, B. S., Norris, P. J., Rosenberg, M. G., and Nixon, D. F. (2008). Suppression of HIV-1 plasma viral load below detection preserves IL-17 producing T cells in HIV-1 infection. AIDS 22, 990-992.

Ndhlovu, L. C., Sinclair, E., Epling, L., Tan, Q. X., Ho, T., Jha, A. R., Eccles-James, I., Tincati, C., Levy, J. A., Nixon, D. F., Hecht, F. M., and Barbour, J. D. (2010b). IL-2 immunotherapy to recently HIV-1 infected adults maintains the numbers of IL-17 expressing CD4+ T (T(H)17) cells in the periphery. J.Clin.Immunol. 30, 681-692.

Ndhlovu, L. C., Sinclair, E., Epling, L., Tan, Q. X., Ho, T., Jha, A. R., Eccles-James, I., Tincati, C., Levy, J. A., Nixon, D. F., Hecht, F. M., and Barbour, J. D. (2010a). IL-2 
immunotherapy to recently HIV-1 infected adults maintains the numbers of IL-17 expressing CD4+ T (T(H)17) cells in the periphery. J.Clin.Immunol. 30, 681-692.

Neumann, A., Polis, M., Rozenberg, L., Jackson, J., Reitano, K., McLaughlin, M., Koratich, C., Dewar, R., Masur, H., Haagmans, B., and Kottilil, S. (2007). Differential antiviral effect of PEG-interferon-alpha-2b on HIV and HCV in the treatment of HIV/HCV co-infected patients. AIDS 21, 1855-1865.

Niedbala, W., Cai, B., Wei, X., Patakas, A., Leung, B. P., McInnes, I. B., and Liew, F. Y. (2008). Interleukin-27 attenuates collagen-induced arthritis. Ann.Rheum.Dis.

Nilssen, D. E., Muller, F., Oktedalen, O., Froland, S. S., Fausa, O., Halstensen, T. S., and Brandtzaeg, P. (1996). Intraepithelial gamma/delta T cells in duodenal mucosa are related to the immune state and survival time in AIDS. J.Virol. 70, 3545-3550.

Nilsson, J., Boasso, A., Velilla, P. A., Zhang, R., Vaccari, M., Franchini, G., Shearer, G. M., Andersson, J., and Chougnet, C. (2006). HIV-1-driven regulatory T-cell accumulation in lymphoid tissues is associated with disease progression in HIV/ AIDS. Blood. 108, 3808-3817.

Nurieva, R. I., Chung, Y., Martinez, G. J., Yang, X. O., Tanaka, S., Matskevitch, T. D., Wang, Y. H., and Dong, C. (2009). Bcl6 mediates the development of T follicular helper cells. Science. 325, 1001-1005.

Oppmann, B., Lesley, R., Blom, B., Timans, J. C., Xu, Y., Hunte, B., Vega, F., Yu, N., Wang, J., Singh, K., Zonin, F., Vaisberg, E., Churakova, T., Liu, M., Gorman, D., Wagner, J., Zurawski, S., Liu, Y., Abrams, J. S., Moore, K. W., Rennick, D., Waal-Malefyt, R., Hannum, C., Bazan, J. F., and Kastelein, R. A. (2000). Novel p19 protein engages IL$12 \mathrm{p} 40$ to form a cytokine, IL-23, with biological activities similar as well as distinct from IL-12. Immunity. 13, 715-725.

Owen, R. E., Heitman, J. W., Hirschkorn, D. F., Lanteri, M. C., Biswas, H. H., Martin, J. N., Krone, M. R., Deeks, S. G., and Norris, P. J. (2010). HIV+ elite controllers have low HIV-specific T-cell activation yet maintain strong, polyfunctional T-cell responses. AIDS. 24, 1095-1105.

Pai, S. Y., Truitt, M. L., and Ho, I. C. (2004). GATA-3 deficiency abrogates the development and maintenance of T helper type 2 cells. Proc.Natl.Acad.Sci.U.S.A. 101, 1993-1998.

Palermo, R. E., Patterson, L. J., Aicher, L. D., Korth, M. J., Robert-Guroff, M., and Katze, M. G. (2011). Genomic analysis reveals pre- and postchallenge differences in a rhesus macaque AIDS vaccine trial: insights into mechanisms of vaccine efficacy. J.Virol. 85, 1099-1116.

Parham, C., Chirica, M., Timans, J., Vaisberg, E., Travis, M., Cheung, J., Pflanz, S., Zhang, R., Singh, K. P., Vega, F., To, W., Wagner, J., O'Farrell, A. M., McClanahan, T., Zurawski, S., Hannum, C., Gorman, D., Rennick, D. M., Kastelein, R. A., de Waal, M. R., and Moore, K. W. (2002). A receptor for the heterodimeric cytokine IL-23 is composed of IL-12Rbeta1 and a novel cytokine receptor subunit, IL-23R. J.Immunol. 168, 5699-5708.

Peng, Q. L., Zhang, M. X., Li, G. Y., Liu, Y. X., Zhou, B. P., and Wang, H. (2010). [Loss of the balance between Th17 and Th1 populations in HIV/AIDS patients]. Zhonghua Shi Yan.He.Lin.Chuang.Bing.Du Xue.Za Zhi. 24, 17-20.

Pflanz, S., Hibbert, L., Mattson, J., Rosales, R., Vaisberg, E., Bazan, J. F., Phillips, J. H., McClanahan, T. K., de Waal, M. R., and Kastelein, R. A. (2004). WSX-1 and glycoprotein 130 constitute a signal-transducing receptor for IL-27. J.Immunol. 172, 2225-2231.

Pflanz, S., Timans, J. C., Cheung, J., Rosales, R., Kanzler, H., Gilbert, J., Hibbert, L., Churakova, T., Travis, M., Vaisberg, E., Blumenschein, W. M., Mattson, J. D., Wagner, J. L., To, W., Zurawski, S., McClanahan, T. K., Gorman, D. M., Bazan, J. F., de Waal, M. R., Rennick, 
D., and Kastelein, R. A. (2002). IL-27, a heterodimeric cytokine composed of EBI3 and p28 protein, induces proliferation of naive CD4(+) T cells. Immunity. 16, 779-790.

Piconi, S., Trabattoni, D., Gori, A., Parisotto, S., Magni, C., Meraviglia, P., Bandera, A., Capetti, A., Rizzardini, G., and Clerici, M. (2010). Immune activation, apoptosis, and Treg activity are associated with persistently reduced CD4+ T-cell counts during antiretroviral therapy. AIDS. 24, 1991-2000.

Prendergast, A., Prado, J. G., Kang, Y. H., Chen, F., Riddell, L. A., Luzzi, G., Goulder, P., and Klenerman, P. (2010). HIV-1 infection is characterized by profound depletion of CD161+ Th17 cells and gradual decline in regulatory T cells. AIDS. \%20;24, 491-502.

Quintana, F. J., Basso, A. S., Iglesias, A. H., Korn, T., Farez, M. F., Bettelli, E., Caccamo, M., Oukka, M., and Weiner, H. L. (2008). Control of T(reg) and T(H)17 cell differentiation by the aryl hydrocarbon receptor. Nature. 453, 65-71.

Raffatellu, M., Santos, R. L., Verhoeven, D. E., George, M. D., Wilson, R. P., Winter, S. E., Godinez, I., Sankaran, S., Paixao, T. A., Gordon, M. A., Kolls, J. K., Dandekar, S., and Baumler, A. J. (2008). Simian immunodeficiency virus-induced mucosal interleukin-17 deficiency promotes Salmonella dissemination from the gut. Nat Med. 14, 421-428.

Romani, B., Engelbrecht, S., and Glashoff, R. H. (2009). Antiviral roles of APOBEC proteins against HIV-1 and suppression by Vif. Arch.Virol. 154, 1579-1588.

Rouse, B. T., Sarangi, P. P., and Suvas, S. (2006). Regulatory T cells in virus infections. Immunol.Rev. 212, 272-286.

Ruckerl, D., Hessmann, M., Yoshimoto, T., Ehlers, S., and Holscher, C. (2006). Alternatively activated macrophages express the IL-27 receptor alpha chain WSX-1. Immunobiology 211, 427-436.

Schulze Zur, W. J., Thomssen, A., Hartjen, P., Toth, I., Lehmann, C., Meyer-Olson, D., Colberg, K., Frerk, S., Babikir, D., Schmiedel, S., Degen, O., Mauss, S., Rockstroh, J., Staszewski, S., Khaykin, P., Strasak, A., Lohse, A. W., Fatkenheuer, G., Hauber, J., and van Lunzen, J. (2011). Comprehensive analysis of frequency and phenotype of $\mathrm{T}$ regulatory cells in HIV infection: CD39 expression of FoxP3+ T regulatory cells correlates with progressive disease. J.Virol. 85, 1287-1297.

Seder, R. A., Gazzinelli, R., Sher, A., and Paul, W. E. (1993). Interleukin 12 acts directly on CD4+ $\mathrm{T}$ cells to enhance priming for interferon gamma production and diminishes interleukin 4 inhibition of such priming. Proc.Natl.Acad.Sci.U.S.A. 90, 10188-10192.

Stockinger, B. (2007). Good for Goose, but not for Gander: IL-2 interferes with Th17 differentiation. Immunity. 26, 278-279.

Suto, A., Kashiwakuma, D., Kagami, S., Hirose, K., Watanabe, N., Yokote, K., Saito, Y., Nakayama, T., Grusby, M. J., Iwamoto, I., and Nakajima, H. (2008). Development and characterization of IL-21-producing CD4+ T cells. J.Exp.Med. 205, 1369-1379.

Szabo, S. J., Sullivan, B. M., Stemmann, C., Satoskar, A. R., Sleckman, B. P., and Glimcher, L. H. (2002). Distinct effects of T-bet in TH1 lineage commitment and IFN-gamma production in CD4 and CD8 T cells. Science 295, 338-342.

Terzieva, V. (2008). Regulatory T cells and HIV-1 infection. Viral Immunol. 21, 285-291.

Thorborn, G., Pomeroy, L., Isohanni, H., Perry, M., Peters, B., and Vyakarnam, A. (2010). Increased sensitivity of CD4+ T-effector cells to CD4+CD25+ Treg suppression compensates for reduced Treg number in asymptomatic HIV-1 infection. PLoS.One. 5 , e9254.

Torheim, E. A., Ndhlovu, L. C., Pettersen, F. O., Larsen, T. L., Jha, A. R., Torgersen, K. M., Kvale, D., Nixon, D. F., Tasken, K., and Aandahl, E. M. (2009). Interleukin-10- 
secreting $\mathrm{T}$ cells define a suppressive subset within the HIV-1-specific T-cell population. Eur.J.Immunol. 39, 1280-1287.

Tran, T. A., de Goer de Herve MG, Hendel-Chavez, H., Dembele, B., Le Nevot, E., Abbed, K., Pallier, C., Goujard, C., Gasnault, J., Delfraissy, J. F., Balazuc, A. M., and Taoufik, Y. (2008). Resting regulatory CD4 T cells: a site of HIV persistence in patients on long-term effective antiretroviral therapy. PLoS.One. 3, e3305.

van Seventer, J. M., Nagai, T., and van Seventer, G. A. (2002). Interferon-beta differentially regulates expression of the IL-12 family members p35, p40, p19 and EBI3 in activated human dendritic cells. J.Neuroimmunol. 133, 60-71.

Villinger, F. and Ansari, A. A. (2010). Role of IL-12 in HIV infection and vaccine. Eur.Cytokine Netw. 21, 215-218.

Weiss, L., Letimier, F. A., Carriere, M., Maiella, S., Donkova-Petrini, V., Targat, B., Benecke, A., Rogge, L., and Levy, Y. (2010). In vivo expansion of naive and activated $\mathrm{CD} 4+\mathrm{CD} 25+\mathrm{FOXP3}+$ regulatory $\mathrm{T}$ cell populations in interleukin-2-treated HIV patients. Proc.Natl.Acad.Sci.U.S.A. 107, 10632-10637.

Weiss, L., Piketty, C., Assoumou, L., Didier, C., Caccavelli, L., Donkova-Petrini, V., Levy, Y., Girard, P. M., Burgard, M., Viard, J. P., Rouzioux, C., and Costagliola, D. (2010). Relationship between regulatory $\mathrm{T}$ cells and immune activation in human immunodeficiency virus-infected patients interrupting antiretroviral therapy. PLoS.One. 5, e11659.

Wirtz, S., Tubbe, I., Galle, P. R., Schild, H. J., Birkenbach, M., Blumberg, R. S., and Neurath, M. F. (2006). Protection from lethal septic peritonitis by neutralizing the biological function of interleukin 27. J.Exp.Med. 203, 1875-1881.

Wong, M. T., Ye, J. J., Alonso, M. N., Landrigan, A., Cheung, R. K., Engleman, E., and Utz, P. J. (2010). Regulation of human Th9 differentiation by type I interferons and IL-21. Immunol Cell Biol. 88, 624-631.

Xing, J., Wu, Y., and Ni, B. (2011). Th9: a new player in asthma pathogenesis? J.Asthma. 48, 115-125.

Xing, S., Fu, J., Zhang, Z., Gao, Y., Jiao, Y., Kang, F., Zhang, J., Zhou, C., Wu, H., and Wang, F. S. (2010). Increased turnover of FoxP3high regulatory $T$ cells is associated with hyperactivation and disease progression of chronic HIV-1 infection. J.Acquir.Immune.Defic.Syndr. 54, 455-462.

Yang, X. O., Pappu, B. P., Nurieva, R., Akimzhanov, A., Kang, H. S., Chung, Y., Ma, L., Shah, B., Panopoulos, A. D., Schluns, K. S., Watowich, S. S., Tian, Q., Jetten, A. M., and Dong, C. (2008). T helper 17 lineage differentiation is programmed by orphan nuclear receptors ROR alpha and ROR gamma. Immunity. 28, 29-39.

Yue, F. Y., Merchant, A., Kovacs, C. M., Loutfy, M., Persad, D., and Ostrowski, M. A. (2008). Virus-specific interleukin-17-producing CD4+ T cells are detectable in early human immunodeficiency virus type 1 infection. J.Virol. 82, 6767-6771.

Zheng, Y. and Rudensky, A. Y. (2007). Foxp3 in control of the regulatory T cell lineage. Nat Immunol. 8, 457-462.

Zhou, L., Lopes, J. E., Chong, M. M., Ivanov, I. I., Min, R., Victora, G. D., Shen, Y., Du, J., Rubtsov, Y. P., Rudensky, A. Y., Ziegler, S. F., and Littman, D. R. (2008). TGF-betainduced Foxp3 inhibits $\mathrm{T}(\mathrm{H}) 17$ cell differentiation by antagonizing RORgammat function. Nature. 453, 236-240.

Zhu, J., Min, B., Hu-Li, J., Watson, C. J., Grinberg, A., Wang, Q., Killeen, N., Urban, J. F., Jr., Guo, L., and Paul, W. E. (2004). Conditional deletion of Gata3 shows its essential function in $\mathrm{T}(\mathrm{H}) 1-\mathrm{T}(\mathrm{H}) 2$ responses. Nat Immunol. 5, 1157-1165. 


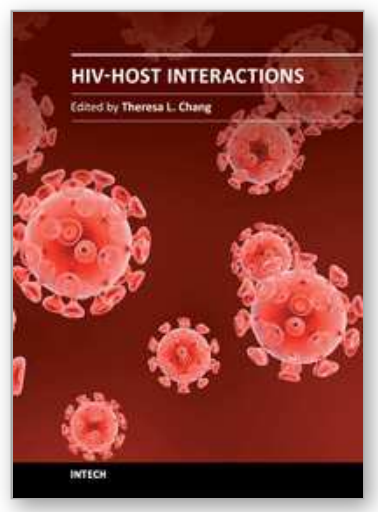

\section{HIV-Host Interactions}

Edited by Dr. Theresa Li-Yun Chang

ISBN 978-953-307-442-9

Hard cover, 364 pages

Publisher InTech

Published online 02, November, 2011

Published in print edition November, 2011

HIV remains the major global health threat, and neither vaccine nor cure is available. Increasing our knowledge on HIV infection will help overcome the challenge of HIV/AIDS. This book covers several aspects of HIV-host interactions in vitro and in vivo. The first section covers the interaction between cellular components and HIV proteins, Integrase, Tat, and Nef. It also discusses the clinical relevance of HIV superinfection. The next two chapters focus on the role of innate immunity including dendritic cells and defensins in HIV infection followed by the section on the impact of host factors on HIV pathogenesis. The section of co-infection includes the impact of Human herpesvirus 6 and Trichomonas vaginalis on HIV infection. The final section focuses on generation of HIV molecular clones that can be used in macaques and the potential use of cotton rats for HIV studies.

\section{How to reference}

In order to correctly reference this scholarly work, feel free to copy and paste the following:

Christina Guzzo, Nor Fazila Che Mat, Xiubo Zhang and Katrina Gee (2011). Impact of HIV Infection and HAART Therapy on CD4 T Helper Cell Subset Expression and Function, HIV-Host Interactions, Dr. Theresa LiYun Chang (Ed.), ISBN: 978-953-307-442-9, InTech, Available from: http://www.intechopen.com/books/hivhost-interactions/impact-of-hiv-infection-and-haart-therapy-on-cd4-t-helper-cell-subset-expression-andfunction

\section{INTECH}

open science | open minds

\section{InTech Europe}

University Campus STeP Ri

Slavka Krautzeka 83/A

51000 Rijeka, Croatia

Phone: +385 (51) 770447

Fax: +385 (51) 686166

www.intechopen.com

\section{InTech China}

Unit 405, Office Block, Hotel Equatorial Shanghai

No.65, Yan An Road (West), Shanghai, 200040, China 中国上海市延安西路65号上海国际贵都大饭店办公楼 405 单元

Phone: +86-21-62489820

Fax: $+86-21-62489821$ 
(C) 2011 The Author(s). Licensee IntechOpen. This is an open access article distributed under the terms of the Creative Commons Attribution 3.0 License, which permits unrestricted use, distribution, and reproduction in any medium, provided the original work is properly cited. 